\title{
Pengembangan Tes Kemampuan Berpikir Kritis untuk Kelas V SD
}

\author{
Dewa Gede Widhya Surya Pratama ${ }^{1 *}$, Kadek Suranata ${ }^{2}$, Ni Wayan Arini ${ }^{3}$ iD \\ 1,3, Prodi Pendidikan Guru Sekolah Dasar, Universitas Pendidikan Ganesha, Bali, Indonesia \\ ${ }^{2}$ Prodi bimbingan Konseling, Universitas Pendidikan Ganesha, Bali, Indonesia \\ *Corresponding author: dewa.gedewidhya@yahoo.com
}

\begin{abstract}
Abstrak
Pada pelaksanaan pembelajaran di kelas guru tidak menekankan pada aspek berpikir kritis dalam proses pembelajaran, ini dikarenakan kurangnya pengetahuan guru mengenai kemampuan berpikir kritis. Rendahnya kemampuan berpikir kritis siswa, maka perlu dikembangkan tes yang standar untuk menilai kemampuan berpikir kritis siswa kelas V. Penelitian ini bertujuan untuk mengetahui proses pengembangan dan untuk mengetahui kualitas tes berpikir kritis yang dikembangkan untuk semester genap kelas V SD ditinjau dari validitas isi dan reliabilitas butir tes. Populasi penelitian ini adalah siswa kelas V SD. Penelitian ini merupakan penelitian pengembangan menggunakan model 4D Thiagarajan. Pengumpulan data dilakukan menggunakan metode pencatatan dokumen, observasi, dan lembar validasi ahli. Instrumen yang digunakan adalah instrumen tes kemampuan berpikir kritis. Metode analisis data yang digunakan adalah uji validitas isi dan uji reliabilitas instrument tes. Hasil uji validitas isi yang didapatkan sebesar 0,937, yang berada pada katagori sangat tinggi yaitu pada rentangan 0,80-1.00. Sedangkan hasil uji reliabilitas istrumen tes dioeroleh sebesar 0,92 dan berada pada katagori sangat tinggi yaitu berada pada rentangan 0,80-1,00. Hal ini berarti, tes kemampuan berpikir kritis yang dikembangkan dapat digunakan sebagai tes standar dalam mengukur kemampuan berpikir kritis siswa kelas $\mathrm{V}$ pada tema delapan, sub-tema tiga.
\end{abstract}

Kata Kunci: Pengembangan, Tes, Berpikir Kritis.

\section{Abstract}

This study aims to know the development process and the quality of critical thinking tests developed for grade $V$ of elementary school in Busungbiu sub district in academic year 2019/2020 in terms of content validity and reliability of test items. This study is a development study using the $4 D$ Thiagarajan model. Data collection were done using the method of recording documents, observations, and expert validation sheets. The instrument used was an instrument of critical thinking skills. Data analysis methods used were content validity test and instrument reliability test. The results of the content validity test were 0,937, which was in the very high category, from the range 0,80-1.00. While the reliability test results obtained were 0.92 and were in the very high category that was in the range of 0.80-1.00. This means that the critical thinking ability test developed can be used as a standard test in measuring the critical thinking skills of fifth grade students on theme eight, subtheme three of elementary school in Busungbiu sub-district in the academic year 2019/2020.

Keyword: Development,Test, Critical Thinking

\section{Introduction}

Kurikulum dalam pendidikan formal di sekolah memiliki peran yang sangat strategis dan menentukan pencapaian tujuan pendidikan yang mencangkup enam aspek yagn diantaranta, aspek intelek, emosi, sosial,motivasi, kematangan, dan teori belajar (Sarinah, 2015; Suryadi, 2020). Kurikulum 2013 merupakan kurikulum yang digunakan di sekolah

$\begin{array}{ll}\text { History: } & \text { Publisher: Undiksha Press } \\ \text { Received : } 20 \text { September } 2020 & \text { Licensed: This work is licensed under } \\ \text { Revised : } 15 \text { October } 2020 & \\ \text { Accepted : } 26 \text { October } 2020 & \text { Creative Commons Attribution 3.0 License } \\ \text { Published : } 1 \text { Desember } 2020 & \end{array}$


dasar dimana kurikulum ini merupakan perbaikan atau penyempurnaan dari Kurikulum Tingkat Satuan Pendidikan (KTSP). Kurikulum 2013 menjadikan kemampuan berpikir kritis sebagai kemampuan yang tercantum dalam kompetensi dasar dan harus dikuasai oleh siswa di sekloah. Kompetensi dasar yang dimaksud yaitu diantaranya mampu merubah diri dalam berperilaku tangguh menghadapi masalah, jujur, disiplin dan dan kritis dalam melakukan aktivitas belajar. Pada kurikulum KTSP sebelumnya suasana pembelajaran belum menunjukkan melajar aktif materi pembelajaran masih berupa hafalan, kemudian proses belajar aktif dikembangkan dalam kurikulum 2013 menjadi pembelajaran aktif dengan materi yang diperkaya dan sesuai kebutuhan peserta didik untuk meningkatkan berpikir kritis dan analitis yang sesuai dengan standar internasional.

Kemampuan berpikir kritis diperlukan dalam memilah informasi dengan cara mengelompokan, mengorganisasikan, mengingat, dan menganalisis informasi (Mas'ula \& Rokhis, 2020; Nugraha, 2018). Kemampuan berpikir kritis adalah suatu keterampilan berpikir dalam pemecahan masalah secara rasional dan efektif serta harus dimiliki seseorang yang dikembangkan dari sejak pendidikan dasar (Puspitasari \& Nurhayati, 2019). Dengan dikembangkan dari tingkat paling dasar diharapkan siswa mampu memecahkan masalah yang dihadapi di dunia pendidikan maupun dalam kehidupan sehari-hari secara logika dan kritis. Berpikir kritis melibatkan keahlian berfikir induktif seperti mengenali hubungan, menganalisis masalah yang bersifat terbuka (dengan banyak kemungkinan penyelesaian), menentukan sebab dan akibat, membuat kesimpulan dan memperhitungkan data yang relevan. Kemampuan berpikir kritis merupakan suatu yang penting dalam pendidikan sehingga perlu dikembangakan pada siswa dengan cara mewujudkan situasi pembelajaran yang mampu menumbuhkan kemampuan berpikir kritis pada siswa harus dimulai dari pembelajaran yang membuat siswa aktif (Hartanto, 2020; Ikhsan et al., 2017; Istianah, 2013; Marfilinda et al., 2019). Begitu pentingnya peranan kemampuan berpikir kritis bagi kehidupan sehari-hari, seharusnya guru dapat membuat suasana pembelajaran yang menyenangkan dan digemari oleh siswa. Pembelajaran di kelas lebih menekankan pada diskusi kelompok membahas topik/permasalahan yang diberikan oleh gurudengan level kognitif yang lebih tinggi. Diskusi kelompok akan membuat siswa lebih aktif, kreatif, dan kritis untuk menggali informasi dalam menyelesaikan permasalahan yang ada dalam kegiatan pembelajaran. Dengan demikian SDM yang dimiliki oleh bangsa Indonesia akan lebih unggul dan berkualitas.

Berdasarkan hasil wawancara dengan guru kelas V di gugus VII Kecamatan Busungbiu yang menyebutkan dalam pelaksanaan pembelajaran di kelas guru tidak menekankan pada aspek berpikir kritis dalam proses pembelajaran, ini dikarenakan kurangnya pengetahuan guru mengenai kemampuan berpikir kritis. Pada saat proses pembelajaran dikelas guru menyatakan bahwa masih terdapat siswa yang belum mampu menjawab soal yang diberikan. Peserta didik masih bingung dan kesulitan dalam menjawab soal-soal karena kemampuan berpikir siswa masih lemah, proses belajar masih didominasi oleh guru. Selain itu siswa juga masih perlu bimbingan dari guru dalam menyelesaikan permasalahan yang diberikan. Guru juga menyatakan bahwa tidak tersedianya instrumen yang layak digunakan untuk mengukur kemampuan berpikir kritis siswa, instrumen yang digunakan biasanya berupa soal soal yang dimuat dalam buku belajar siswa yang hanya mengukur kemampuan berpikir tingkat rendah yaitu $\mathrm{C} 1, \mathrm{C} 2$, dan $\mathrm{C} 3$. Selain itu guru juga belum mampu menyusun soal yang sesuai dengan indikator kemampuan berpikir kritis. Sehingga perlunya dikembangkan tes kemampuan berpikir kritis untuk kelas V SD di gugus VII Kecamatan Busungbiu. Serta, hasil observasi menunjukkan di SD Gugus VII Kecamatan Busungbiu khususnya di kelas V dalam kegiatan 
belajar di sekolah dilihat bahwa siswa tidak aktif dalam mengikuti pembelajaran. Peserta didik juga kurang mengerti dengan materi yang disampaikan oleh guru ketika proses pembelajaran berangsung. Selain itu, kemampuan berpikir kritis siswa masih sangat rendah dalam mengerjakan soal yang diberikan oleh guru. Ini dikareakan oleh proses belajar siswa masih cenderung mendengarkan dan menghapal materi yang diberikan guru. Dari hasil temuan yang diperoleh di lapangan dengan melihat secara langsung proses pembelajaran yang dilakukan oleh guru ada dua faktor yang menyebabkan kemampuan berpikir kritis siswa rendah, yaitu faktor dari guru dan siswa itu sendiri. Dari faktor guru, guru belum mampu menerapkan model pembelajaran yang membuat siswa aktif, guru masi menggunakan model konvensional, yaitu berpusat pada guru dengan memberikan ceramah dan penugasan, sehingga terjadi proses pembelajaran yang menyenangkan dan membuat siswa aktif. Selain itu, salah satu penyebab kemampuan berpikir kritis siswa rendah adalah soal-soal yang dibuat oleh guru tidak memuat kemampuan berpikir secara kritis. Penyebabnya yaitu guru tidak memiliki pengalaman dalam menyusun soal yang mengukur kemampuan berpikir tingkat tinggi siswa. Berikutnya berpikir kritis belum dikembangkan oleh guru dalam proses pembelajaran di kelas karena belum ada istrumen yang sesuai untuk mengukurnya. Sedangkan dari faktor siswa, siswa kurang perhatian terhadap materi yang dijelaskan oleh guru. Siswa juga tidak bersemangat dalam mengikuti pembelajaran dikelas, sehingga kemamampuan berpikir kritis siswa kelas V di Gugus VII Kecamatan Busungbiu masih rendah.

Untuk mengatasi permasalahan rendahnya kemampuan berpikir kritis siswa kelas $\mathrm{V}$ di Gugus VII Kecamatan Busungbiu, maka perlu dikembangkan tes yang standar untuk menilai kemampuan berpikir kritis siswa kelas V. Butir soal yang dibuat nantinya dapat digunakan guru untuk menumbuhkan kemampuan berpikir kritis siswa dikelas dalam proses pembelajaran. Penerapan penilaian kemampuan berpikir kritis sering dilakukan dengan menggunakan tes tertulis yang merupakan salah satu jenis alat penilaian berbasis kelas, pada penyajian maupun penggunaannya dalam bentuk tulisan.Siswa memberikan jawaban atas pertanyaan maupun tanggapan yang diberikan (Made et al., 2017; MUKTI \& ISTIYONO, 2018). Tes ini juga merupakan alat penilaian berbasis kelas. Untuk pengerjaan nya tes ini dikatakan tidak begitu sulit siswa hanya menuliskan jawaban dari soal yang diberikan dalam sebuah lembar jawaban atau kertas. Tes tertulis ini dapat diberikan pada saat ulangan harian atau ulangan umum. Salah satu contohnya adalah tes berpikir kritis. Dalam proses evaluasi, seorang pendidik tak lepas dari yang namanya penggunaan instrument (Manfaat \& Nurhairiyah, 2013).

Adapun penelitia yang relevan dilakukan oleh Wijayanti, (2015) mendapatkan hasil bahwa pertama kemampuan berpikir kritis siswa kelas V SD No. 1 Kaliuntu ditunjukkan dengan rata-rata skor kemampuan berpikir kritis siswa sebesar 17,95 tergolong rendah dan persentase skor total kemampuan berpikir kritis siswa sebesar 30,61 \% tergolong sangat rendah. Indikator kemampuan berpikir kritis dengan persetase skor terkecil di SD ini adalah kemampuan melakukan induksi sebesar $13 \%$. Kemampuan berpikir kritis siswa kelas V SD No. 2 Kaliuntu ditunjukkan dengan ratarata skor kemampuan berpikir kritis siswa sebesar 17 tergolong rendah dan persentase skor total kemampuan berpikir kritis siswa sebesar 28,54\% tergolong sangat rendah. Indikator kemampuan berpikir kritis dengan persetase skor terkecil di SD ini adalah kemampuan melakukan induksi sebesar $7 \%$. Kemampuan berpikir kritis siswa kelas V SD No. 3 Kaliuntu ditunjukkan dengan rata-rata skor kemampuan berpikir kritis siswa sebesar 9,46 tergolong sangat rendah dan persentase skor total kemampuan berpikir kritis siswa sebesar 17,31 \% tergolong sangat rendah. Indikator kemampuan berpikir kritis dengan persetase skor terkecil di SD ini adalah kemampuan melakukan induksi sebesar $10 \%$. Penelitian yang dilakukan oleh Hartanto, (2020) profil kemampuan berpikir kritis siswa kelas V Sekolah Dasar dari masing-masing aspek elementary clarification kategori 
"Tinggi" presentase 52\%, basic suppor kategori "Tinggi" presentase 54\%, inference kategori "Sedang" presentase 46\%, advanced clarification kategori "Sedang" presentase 54\% dan strategy and tectics kategori "Sedang" presentase 62\%. Penelitian yang dilakukan oleh Selegi, (2019) mendapatkan hasil bahwa kemampuan berpikir kreatif mahasiswa memiliki hasil yang baik. Fluency (kelancaran), flexibility (keluwesan), originality (keaslian), dan elaboration (keterincian) dapat dilakukan dengan saling melengkapi antar bagian. Mahasiswa dibutuhkan waktu yang banyak untuk lebih mengembangkan kemampuan yang mereka miliki menjadi hasil yang bermanfaat. Melalui kemampuan berpikir kreatif mampu meningkatkan soft skills mahasiswa dalam mendesain soal tes bentuk uraian kelas V (lima) SD.

Adapun tujuan dari penelitian ini adalah untuk mengetahui pengembangan tes kemampuan berpikir kritis untuk kelas V SD. Mengemukakan bahwa tes merupakan suatu alat yang digunakan untuk mengumpulkan fakta atau informasi serta memiliki tiga fungsi yaitu, (1) fungsi tes untuk kelas misalnya tes digunakan untuk meningkatkan prestasi siswa, (2) fungsi tes untuk bimbingan yaitu tes digunakan untuk menunjang siswa dalam menentukan pilihan terhadap sesuatu, dan (3) fungsi tes untuk administrasi misalnya untuk menilai kurikulum. Dari bentuk pelaksanaannya, tes dikelompokkan menjadi 3 bentuk. Pertama tes tertulis, dalam pengerjaannya siswa meberikan jawaban mengenai soal yang telah diberikan dengancara menulikannya pada lembar jawaban atau kertas. Kedua tes lisan, dalam pengerjaan nya siswa menjawab pertanyaan yang diberikan dengan cara lisan atau mengucapkan jawaban secara langsung tanpa harus menulis dikertas atau lembar jawaban. Ketiga tes unjuk kerja, dalam pengerjaannya siswa menunjukkan keterampilan yang dimilikinya dalam mengerjakan suatu tes.

\section{Materials and Methods}

Penelitian ini termasuk kedalam jenis penilitian pengembangan. Penelitian pengembangan merupakan metode yang digunakan untuk mengahsilkan suatu produk tertentu, produk yang dihasilkan dapat berupa bahan ajar, instrumen tes, dan lainnya. Pada penelitian ini melakukan pengembangan tes kemampuan berpikir kritis siswa pada tema delapan, sub-tema tiga.Tingkat kelayakan tes kemampuan berpikir kritis ini diketahui melalui validasi oleh ahli materi dan kesesuaian tes. Populasi dari peneliltian ini adalah siswa kelas V SD. Model yang digunakan dalam pengembangan ini mengadopsi model pengembangan 4D (Four-D). seseuai dengan namanya moden 4D memiliki empat tahapan yang akan dilalui dalam proses pengembangan suatu produk. Tahapan tersebut yaitu; define, design, develop, dan disseminate dan dapat diartikan sebagai tahap pendefinisian, tahap perancangan, tahap pengembangan, dan tahap penyebaran. Model ini digunakan karena modah dipahami, proses pengembangannya terdiri dari empat tahapan yng sangat efektif untuk digunakan dalam mengen bangkan instrumen tes. Selain itu pemeilihan model ini juga didasari karena terbatasnya pengetahuan tentang model pengembangan lainnya. Oleh karena itu moden 4D ini sangat cocok digunakan untuk mengembangkan tes kemampuan berpikir kritis pada siswa kelas V SD.

Fase dari model ini dibagi menjadi 3 fase yaitu 1) Tahap Pendefinisian. Proses pengembangan ini diawali dengan mengidentifikasi masalah yang ditemuai disekolah. Pada tahap ini dilakukan analisis terhadap kebutuhan sekolah terkait kebutuhan tes untuk menilai kemampuan berpikir kritis siswa. Melakukan analisis terhadap subjek sasaran pengukuran. Tahap pendefinisian bertujuan untuk menemukan permasalahakn yang ada dan mengidentifikasi kebutuhan dalam penyusunan soal seperti materi, kompetensi dasar, indikator, tujuan pembelajaran yang telah ditentukan dalam pembelajaran dikelas serta tujuan melaksanakan tes. Selain itu pada tahap ini dilakukan pengumpulan sumber-sumber untuk menemukan konsep dari variabel dalam pengembangan ini dan menemukan dasar teori tentang proses pengembangan yang akan dilakukan. 2) Tahap Perancangan. Dalam tahap 
perancangan dilakukan kegiatan menyusun kerangka tes kemapuan berpikir kritis untuk tema delapan sub-tema tiga kelas V SD berdasarkan indikator dan tujuan pembelajaran. Pada tahap ini menyusun blue prin (kisi-kisi) istrumen dan dan butir-butir soal berdasarkan kajian analisis tingkat perkembangan anak dan indikator krmampuan berpikir kritis yang telah dianalisis. tingkat tinggi antara C3-C6. 3) Tahap Pengembangan. Pada tahap pengembangan kegiatan yang dilakukan bertujuan untuk memperolah atau mengahasilkan istrumen tes yang sesuai dengan standar tes yang baik. Pada tahap ini juga dilakukan pengecekan butir tes yang dilakukan oleh ahli untuk mengetahui tingkat validasi dan reliabilitas tes yang telah dikembangakan. Selanjutnya, instrumen hasil pengembangan tersebut divalidasi oleh para ahli. Istrumen yang digunakan dalam pengembangan ini adalah lembar observasi untuk mengumpulkan data hasil review dari ahli. Validasi isi dilakukan oleh dua dosen Fakultas Ilmu Pendidikan Universitas Pendidikan Ganesha. Validasi isi dilakukan agar mendapat saran dari para ahli. Kemudian butir soal tes direvisi sesuai dengan saran para ahli. Selanjutnya hasil validasi isi juga dianalisis formula gregory.

Untuk mengetahui kualitas tes kemampuan berpikir kritis dilakukan beberapa analisis yaitu, 1) uji validitas isi tes dan, 2) uji reliabilitas tes. Pada tahap ini instrumen tes kemampuan berpikir kritis dinilai oleh ahli . penilaian tersebut dilakukan untuk mengetahui validitas soal yang akan digunakan. Uji reliabilitas dilakukan untuk mengetahui apakah istrumen itu tetap atu digunakan untuk mengetahui kekekalan intrumen tes tersebut. Instrumen pengumpulan data dalam penelitian ini adalah melalui lembar observasi yaitu relevansi untuk validasi yang di isi oleh 2 dosen mata pelajaran IPA dengan menggunakan rumus Gregory.

\section{Results and Discussion}

\section{Hasil Penelitian}

Penyusunan pengembangan tes kemampuan berpikir kritis telah dilakukan sesuai dengan prosedur pengembangan sehingga menghasilkan tes yang baik digunakan untuk mengukur kemampuan berpikir kritis siswa kelas V pada tema delapan sub-tema tiga. Produk akhir dari pengembangan ini adalah tes kemampuan berpikir kritis siswa kelas 5 di gugus VII kecamatan busungbiu tahun pelajaran 2019/2020 pada tema delapan sub-tema tiga. Proses pengembangan tes kemampuan berpikir kritis yang dikembangkan dengan model 3P dibagi menjadi 3 tahap yaitu, 1) tahap pendefinisian, yaitu pada tahap ini dilakukan pengumpulan reverensi sesuai dengan variabel yang dikembangkan yakni tentang penelitian pengembangan, tes kemampuan berpikir kritis siswa. Dari referensi-referensi kemampuan berpikir kritis didapatkan beberapa teori yang telah ditemukan oleh ahli-ahli yang berkaitan dengan pengembangan ini. Salah satunya teory dari Robert H. Ennis. Teori kemampuan berpikir tingkat tinggi menurut Taksonomi Bloom. Teori Taksonomi Bloom menjelaskan bahwa kemampuan berpikir tingkat tinggi diklasifikasikan pada 3 ranah kognitif yaitu menganalisis, mengevaluasi, dan mengkreasi. 2) tahap perancangan. Tahapan ini bertujuan untuk merancang sebuah instrumen tes kemampuan berpikir tingkat tinggi. Instrumen tes yang akan dirancang terdiri dari kisi-kisi, soal tes berupa uraian, kriteria jawaban, dan pedoman penilaian. pada tahap ini merupakan bagian mendesain/merancang bentuk soal berdasarkan indikator dan tujuan pembelajaran. 3) tahap pengembangan. Tahap development bertujuan untuk menghasilkan perangkat tes yang valid berdasarkan penilaian ahli yaitu ahli evaluasi, dan materi dengan menggunakan instrumen berupa lembar validasi

Kualitas tes kemampuan bepikir kritis untuk kelas V SD pada tema delapan sub-tema tiga, yaitu Analisis validitas isi tes berpikir kritis berdasarkan evaluasi uji ahli isi terdiri atas

2 orang dosen fakultas ilmu pendidikan, yaitu bapak Dr. Kadek Suranata, S.Pd., M.Pd., Kons. Dan bapak Dr. I Gede Astawan, S.Pd.,M.Pd. Setelah dilakukan uji ahli selanjutnya 
dilakukan uji coba Gregory, hasil perhitungan koefisien isi didapatkan sebesar 0,937. Sesuai dengan tabel klasifikasi validitas, maka validitas isi instrumen tes berpikir kritis berada pada kategori sangat tinggi, yaitu berada pada rentangan 0,80-1,00. Artinya, instrumen tes berpikir kritis bisa digunakan dalam menilai kemampuan berpikir kritis siswa kelas V SD. Selanjutnya dilakukan uji reliabiltas tes. Pelaksanaan uji reliabilitas dilakukan berdasarkan atas hasil uji ahli yang telah dilaksanakan sebelumnya. uji reliabilitas dilakukan menggunakan rumus alpha cronbach didapatkan yaitu sebesar 0.92. Sesuai dengan tabel klasifikasi reliabilitas istrumen tes, maka reliabilitas tes yang telah disusun berada dalam katagori reliabilitas sangat tinggi, dengan rentangan nilai hasil analisis yang diperoleh terdapat pada rentangan 0,80-1,00. Artinya, soal tes yang telah dibuat reliabel untuk digunakan dan memiliki ketetapan atau memiliki hasil yang relatif sama meski digunakan dalam kurun waktu dan situasi yang berbeda untuk melakukan penilaian.

Prosedur Pengembangan Tes Kemampuan Berpikir Kritis. Pengembangan instrumen tes untuk mengukur kemampuan berpikir kritis telah melalui serangkaian tahap pengembangan model 3P mulai dari tahap pendefinisian, tahap perancangan, dan tahap penegmbangan, sehingga menghasilkan sebuah produk. Produk yang dimaksud tersebut adalah tes untuk mengukur kemampuan berpikir kritis kelas $\mathrm{V}$ pada tema delapan, sub-tema tiga. Sebelum proses pengembangan dilakukan, telah ditetapkan suatu kriteria kualitas instrumen tes untuk melihat sejauh mana keberhasilan produk yang dihasilkan.

Tahap Pendefinisian. Proses pengembangan ini diawali dengan mengidentifikasi masalah yang ditemuai disekolah. Pada tahap ini dilakukan analisis terhadap kebutuhan sekolah terkait kebutuhan tes untuk menilai kemampuan berpikir kritis siswa. Melakukan analisis terhadap subjek sasaran pengukuran. Tahap pendefinisian bertujuan untuk menemukan permasalahakn yang ada dan mengidentifikasi kebutuhan dalam penyusunan soal seperti materi, kompetensi dasar, indikator, tujuan pembelajaran yang telah ditentukan dalam pembelajaran dikelas serta tujuan melaksanakan tes. Selain itu pada tahap ini dilakukan pengumpulan sumber-sumber untuk menemukan konsep dari variabel dalam pengembangan ini dan menemukan dasar teori tentang proses pengembangan yang akan dilakukan.

Tahap Perancangan. Dalam tahap perancangan dilakukan kegiatan menyusun kerangka tes kemapuan berpikir kritis untuk tema delapan sub-tema tiga kelas V SD berdasarkan indikator dan tujuan pembelajaran. Pada tahap ini menyusun blue prin (kisi-kisi) istrumen dan dan butir-butir soal berdasarkan kajian analisis tingkat perkembangan anak dan indikator krmampuan berpikir kritis yang telah dianalisis. Jenis tes yang akan dikembangakan adalah soal esai (uraian) yang sesuai dengan kisi-kisi, indikator, dan tingkat kognitif yang telah dirancang. Bentuk soal yang akan dibuat berdasarkan aspek revisi Taksonomi Bloom, yaitu dengan memperhatikan level kognitif tingkat tinggi antara C3-C6.

Tahap Pengembangan. Pada tahap pengembangan kegiatan yang dilakukan bertujuan untuk memperolah atau mengahasilkan istrumen tes yang sesuai dengan standar tes yang baik. Pada tahap ini juga dilakukan pengecekan butir tes yang dilakukan oleh ahli untuk mengetahui tingkat validasi dan reliabilitas tes yang telah dikembangakan. Untuk analisis uji validasi dan reliabilitas disajikan dalam tabel 1.

Table 1. Hasil Analisis Validitas Dan Reliabilitas Tes Kemampuan Berpikir Kritis

\begin{tabular}{lll}
\hline Analisis & Hasil & Kriteria \\
\hline Validitas & 0,937 & Sangat Tinggi \\
\hline Reliabilitas & 0.92 & Sangat Tinggi \\
\hline
\end{tabular}


Berdasarkan tabel 1 diatas menjelaskan kualitas Tes Kemampuan Berpikir Kritis. Sesuai dengan hasil penilaian oleh dua pakar mendapatkan hasil yang telah dijelaskan ahli 1 menyebutkan bahwa soal nomor 1 tidak sesuai atau tidak valid, dan ahli 2 menyatakan semua butir soal dinyatakan valid, sesuai dengan hasil uji judges didapatkan hasil validitas sebesar 0,937 . Sesuai dengan tabel indeks validasi menyatakan bahwa validitas tes yang disusun berada pada katagori sangat tinggi, dengan rentangan nilai 0,80-1,00. Melihat hasil tersebut dapat dinyatakan bahwa tes yang telah disusun memenuhi syarat validitas dan layak digunakan untuk siswa kelas V SD.

\section{Pembahasan}

Reliabilitas Instrumen Tes Berdasarkan analisis uji reliabilitas yang dianalisis menggunakan rumus alpha cronbach didapatkan yaitu sebesar. Sesuai dengan tabel klasifikasi reliabilitas istrumen tes, maka reliabilitas tes yang telah disusun berada dalam katagori reliabilitas sangat tinggi, dengan rentangan nilai hasil analisis yang diperoleh terdapat pada rentangan 0,80-1,00. Artinya, soal tes yang telah dibuat reliabel untuk digunakan dan memiliki ketetapan atau memiliki hasil yang relatif sama meski digunakan dalam kurun waktu dan situasi yang berbeda untuk melakukan penilaian. Tes tertulis adalah suatu arah yang digunakan untuk menilai kemampuan peserta didik yang pengerjaanyan dilakukan secara tertulis. Tes ini juga merupakan alat penilaian berbasis kelas. Untuk pengerjaan nya tes ini dikatakan tidak begitu sulit siswa hanya menuliskan jawaban dari soal yang diberikan dalam sebuah lembar jawaban atau kertas. Tes tertulis ini dapat diberikan pada saat ulangan harian atau ulangan umum. Salah satu contohnya adalah tes berpikir kritis. Kemampuan berpikir kritis diperlukan dalam memilah informasi dengan cara mengelompokan, mengorganisasikan, mengingat, dan menganalisis informasi (Mas'ula \& Rokhis, 2020; Nugraha, 2018). Kemampuan berpikir kritis adalah suatu keterampilan berpikir dalam pemecahan masalah secara rasional dan efektif serta harus dimiliki seseorang yang dikembangkan dari sejak pendidikan dasar (Puspitasari \& Nurhayati, 2019; Rosy \& Pahlevi, 2015). Dengan dikembangkan dari tingkat paling dasar diharapkan siswa mampu memecahkan masalah yang dihadapi di dunia pendidikan maupun dalam kehidupan sehari-hari secara logika dan kritis. Berpikir kritis melibatkan keahlian berfikir induktif seperti mengenali hubungan, menganalisis masalah yang bersifat terbuka (dengan banyak kemungkinan penyelesaian), menentukan sebab dan akibat, membuat kesimpulan dan memperhitungkan data yang relevan (Nuriani, 2014). Kemampuan berpikir kritis merupakan suatu yang penting dalam pendidikan sehingga perlu dikembangakan pada siswa dengan cara mewujudkan situasi pembelajaran yang mampu menumbuhkan kemampuan berpikir kritis pada siswa harus dimulai dari pembelajaran yang membuat siswa aktif (Hartanto, 2020; Ikhsan et al., 2017; Istianah, 2013; Marfilinda et al., 2019). Begitu pentingnya peranan kemampuan berpikir kritis bagi kehidupan sehari-hari, seharusnya guru dapat membuat suasana pembelajaran yang menyenangkan dan digemari oleh siswa. Pembelajaran di kelas lebih menekankan pada diskusi kelompok membahas topik/permasalahan yang diberikan oleh gurudengan level kognitif yang lebih tinggi. Diskusi kelompok akan membuat siswa lebih aktif, kreatif, dan kritis untuk menggali informasi dalam menyelesaikan permasalahan yang ada dalam kegiatan pembelajaran. Dengan demikian SDM yang dimiliki oleh bangsa Indonesia akan lebih unggul dan berkualitas.

Adapun penelitia yang relevan dilakukan oleh Wijayanti, (2015) mendapatkan hasil bahwa pertama kemampuan berpikir kritis siswa kelas V SD No. 1 Kaliuntu ditunjukkan dengan rata-rata skor kemampuan berpikir kritis siswa sebesar 17,95 tergolong rendah dan persentase skor total kemampuan berpikir kritis siswa sebesar 30,61\% tergolong sangat rendah. Indikator kemampuan berpikir kritis dengan persetase skor terkecil di SD ini adalah kemampuan melakukan induksi sebesar $13 \%$. Kemampuan berpikir kritis siswa kelas V SD 
No. 2 Kaliuntu ditunjukkan dengan ratarata skor kemampuan berpikir kritis siswa sebesar 17 tergolong rendah dan persentase skor total kemampuan berpikir kritis siswa sebesar 28,54\% tergolong sangat rendah. Indikator kemampuan berpikir kritis dengan persetase skor terkecil di SD ini adalah kemampuan melakukan induksi sebesar $7 \%$. Kemampuan berpikir kritis siswa kelas V SD No. 3 Kaliuntu ditunjukkan dengan rata-rata skor kemampuan berpikir kritis siswa sebesar 9,46 tergolong sangat rendah dan persentase skor total kemampuan berpikir kritis siswa sebesar 17,31 \% tergolong sangat rendah. Indikator kemampuan berpikir kritis dengan persetase skor terkecil di SD ini adalah kemampuan melakukan induksi sebesar $10 \%$. Penelitian yang dilakukan oleh Hartanto, (2020) profil kemampuan berpikir kritis siswa kelas V Sekolah Dasar dari masing-masing aspek elementary clarification kategori "Tinggi" presentase 52\%, basic suppor kategori "Tinggi" presentase 54\%, inference kategori "Sedang" presentase 46\%, advanced clarification kategori "Sedang" presentase $54 \%$ dan strategy and tectics kategori "Sedang" presentase 62\%. Penelitian yang dilakukan oleh Selegi, (2019) mendapatkan hasil bahwa kemampuan berpikir kreatif mahasiswa memiliki hasil yang baik. Fluency (kelancaran), flexibility (keluwesan), originality (keaslian), dan elaboration (keterincian) dapat dilakukan dengan saling melengkapi antar bagian. Mahasiswa dibutuhkan waktu yang banyak untuk lebih mengembangkan kemampuan yang mereka miliki menjadi hasil yang bermanfaat. Melalui kemampuan berpikir kreatif mampu meningkatkan soft skills mahasiswa dalam mendesain soal tes bentuk uraian kelas V (lima) SD.

\section{Conclusion}

Penelitian yang dilalakukan menghasilkan produk berupa tes yang dapat dugunakan untuk mengukur kemampuan berpikir kritis siswa kelas $\mathrm{V}$ pada tema delapan, sub-tema tiga. Tes ini berupa tes uraian dengan jumlah soal sebanyak 16 butir dengan level kognitif C3 (mengaplikasikan), C4 (menganalisis), C5 (mengevaluasi), dan C6 (mencipta).Tes kemampuan berpikir kritis yang dikembangakan telah memenuhi syarat validitas isi oleh pakar (ahli). Validitas isi instrumen tes kemampuan berpikir kritis berada pada katagori sangat tinggi, yaitu berada pada rentangan 0,80-1,00. Hasil reliabilitas tes kemampuan berpikir kritis diperoleh nilai sebesar 0,92 . berdasarkan kriteria reliabilitas, maka tes kemampuan berpikir kritis tergolong sangat tinggi.

\section{Suggestion}

Berdasarkan hasil pengembangan tes kemampuan berpikir kritis ini, maka dapat disarankan hal-hal sebagai berikut.

Kepada Siswa. Siswa harus selalu melatih dan mengasah kemampuan berpikir kritis agar mampu menyelesaikan permasalahan baik dalam proses pembelajaran maupun kegiatan sehari-hari. Kepada Guru. Guru diharapkan menggunakan istrumen tes yang dikembangkan ini sebagai alat evaluasi dalam pembelajaran untuk mengukur kemampuan berpikir kritis siswa, sehingga kemampuan berpikir krittis siswa dapat selalu terasah dan dapan berkembang dengan baik. Kepada Sekolah. Sekolah hendaknya mendorong guru-guru untuk mengembangkan tes kemampuan berpikir kritis. Produk pada pengembangan ini dapat digunakan referensi dalam menyusun tes yang lebih luas pada materi pembelajaran laiannya. Bagi Peneliti Lain Instrumen Tes yang dikembangkan pada pengembangan ini memeliki cangkupan sangat terbatas yaitu hanya pada tema delapan, sub-tema tiga dan untuk kelas $\mathrm{V}$ semester genap di Gugus VII Kecamatan Busungbiu. Peneliti lain diharapkan mampu mengembangkan istrumen tes yang memiliki cangkupan lebih luas.

\section{References}

Hartanto. (2020). Pengembangan Instrumen Asesmen Kemampuan Berpikir Kritis Siswa Kelas V Sekolah Dasar Pada Pelajaran Tematik. Akrab Juara, 5(1), 43-54. 
Ikhsan, M., Munzir, S., \& Fitria, L. (2017). Kemampuan Berpikir Kritis dan Metakognisi Siswa dalam Menyelesaikan Masalah Matematika melalui Pendekatan Problem Solving. AKSIOMA: Jurnal Program Studi Pendidikan Matematika, 6(2), 234. https://doi.org/10.24127/ajpm.v6i2.991

Istianah, E. (2013). Meningkatkan Kemampuan Berpikir Kritis Dan Kreatif Matematik Dengan Pendekatan Model Eliciting Activities (Meas) Pada Siswa Sma. Infinity Journal, 2(1), 43. https://doi.org/10.22460/infinity.v2i1.23

Made, N., Widyastini, T., Riastini, P. N., \& Sudana, D. N. (2017). Semester Gasal Kelas Iv Sd. 5 No: 3 Tahun: 2017.

Manfaat, B., \& Nurhairiyah, S. (2013). Pengembangan Instrumen Tes Untuk Mengukur Kemampuan Penalaran Statistik Mahasiswa Tadris Matematika. Eduma: Mathematics Education Learning and Teaching, 2(2). https://doi.org/10.24235/eduma.v2i2.41

Marfilinda, R., Fitria, Y., \& Marsidin, S. (2019). Pengaruh Model Learning Cycle 7 E Dan Pengetahuan Awal Terhadap Keterampilan Berpikir Kritis Siswa Pada Pembelajaran Ipa Di Kelas V Sd. Jurnal Ilmiah Pendidikan Dasar, 6(2), 84. https://doi.org/10.30659/pendas.6.2.84-97

Mas'ula, N., \& Rokhis, T. A. (2020). Pengembangan Instrumen Tes Kemampuan Berpikir Spasial Bagi Siswa SMA. Geodika: Jurnal Kajian Ilmu Dan Pendidikan Geografi, 4(1), 1-10. https://doi.org/10.29408/geodika.v4i1.1823

MUKTI, T. S., \& ISTIYONO, E. (2018). Instrumen Penilaian Kemampuan Berpikir Kritis Peserta Didik SMA Negeri Mata Pelajaran Biologi Kelas X. Jurnal Pendidikan Biologi, 11(2), 105-110.

Nugraha, W. S. (2018). Peningkatan Kemampuan Berpikir Kritis Dan Penguasaan Konsep Ipa Siswa Sd Dengan Menggunakan Model Problem Based Learning. EduHumaniora| Jurnal Pendidikan Dasar Kampus Cibiru. https://doi.org/10.17509/eh.v10i2.11907

Nuriani, N. R. (2014). Efektifitas Penggunaan Metode Pembelajaran Inquiry Berbantuan Pendekatan Mind Mapping terhadap Kemampuan Berpikir Kritis Matematika. Jurnal Derivat, 1(1), 8-18. https://doi.org/https://doi.org/10.31316/j.derivat.v4i1.233

Puspitasari, Y., \& Nurhayati, S. (2019). Pengaruh Model Pembelajaran Discovery Learning Terhadap Hasil Belajar Siswa. Jurnal Pendidikan Dan Kewirausahaan, 7(1), 93-108. https://doi.org/10.47668/pkwu.v7i1.20

Rosy, B., \& Pahlevi, T. (2015). Penerapan Problem Based Learning untuk Meningkatkan Kemampuan Berpikir Kritis dan Keterampilan Memecahkan Masalah. Prosiding Seminar Nasional, 160-175.

Sarinah. (2015). Pengantar Kurikulum. Deepublish.

Selegi, S. F. (2019). Analisis Kemampuan Berpikir Kreatif Mahasiswa PGSD Dalam Mendesain Soal Tes Bentuk Uraian Untuk Meningkatkan Soft Skills Mahasiswa. 3.

Suryadi, A. (2020). Pengembangan Kurikulum. CV Jejak.

Wijayanti, A. I., Pudjawan, K., \& Margunayasa, I. G. (2015). Analisis Kemampuan Berpikir Kritis Siswa Kelas V Dalam Pembelajaran IPA Di 3 SD Gugus X Kecamatan Buleleng. E-Journal PGSD Universitas Pendidikan Ganesha, 3(1), 1-12. 